\title{
Note on Critical issues with Boil-0ff Gas Generating from Marine Fuel LNG
}

\author{
Daejun Chang* \\ Department of Mechanical Engineering, Korea Advanced Institute of Science and Technology, Korea
}

Submission: February 17, 2017; Published: March 22, 2017

*Corresponding author: Daejun Chang, Graduate School of Ocean Systems Engineering, Department of Mechanical Engineering, Korea Advanced Institute of Science and Technology, Republic of Korea, Email: djchang@kaist.ac.kr

\section{Short Communication}

The Marine Environment Protection Committee (MEPC) of the International Maritime Organization (IMO) decided at its 70th session in London in October 2016 that the $0.5 \%$ sulphur cap for marine fuels hall be globally implemented from 2020.This decision is in line with public opinion and global collaboration with respect to reducing the marine pollutants such as SOx, NOx, particulate matters, and even green-house gases emitted by ships $[1,2]$. Three options seem available for ship owners: lowsulphur fuel, scrubbers, and LNG (liquefied natural gas) fuel.

Of the alternatives, the LNG solution clearly shows the best environmental performance since this cryogenic fuel is free from sulphur and particulate matters with a significant potential for $\mathrm{CO} 2$ reduction [3]. Even in the event of fuel leakage, LNG just vaporizes into the atmosphere without significant impact on marine ecosystem. However, some challenges are identified for this solution regarding economics, safety, and environmental friendliness that are mainly related with the boil-off gas (BOG) from the cryogenic liquid fuel.

LNG is stored within a heavily insulated tank around-160 ${ }^{\circ} \mathrm{C}$ under the vapor pressure ranging from the atmospheric pressure up to 10 barg. Due to the large temperature difference from the surroundings, heat ingress into the tank, insulation, and connected piping leads to BOG generation. Unless the BOG is removed from the tank, the tank pressure increases gradually with time. So, there are two kinds of tanks in terms of operating pressure: pressure tanks and non-pressure tanks. The former hold the BOG within it at the expense of pressure rise while the latter emit BOG to keep the internal pressure near the atmospheric pressure. The IGC and IGF codes [4,5] further classify the LNG tanks depending on the installation type and need of secondary barrier against leakage from the tanks as shown in Table 1. Only Type $\mathrm{C}$ tanks are pressure vessels that can keep BOG inside and have no secondary barrier due to their invulnerability against leakage. The flammable gas BOG plays a critical role in judging safety and economics of ships carrying refrigerated fluids [6-9]. In order for non-pressure vessels of Type A, Type B, and membrane tanks to be used for LNG storage, BOG should be vented from the tanks and handled in appropriate ways such as re liquefying, burning, using as fuel, or exporting externally the BOG. Though all these approaches to BOG handling accompany dedicated equipment, trained crew, and additional expense, they make an economic sense for very large LNG carriers that are equipped with those non-pressure tanks $[6,7]$. To the contrary, the fuel LNG tanks for small ships have been of Type $C$ tanks for the sake of no need of BOG handling.

Table 1: IMO classification of LNG tank $[4,5]$

\begin{tabular}{|c|c|c|c|}
\hline $\begin{array}{c}\text { Installation } \\
\text { Type }\end{array}$ & Tank Type & $\begin{array}{c}\text { Design } \\
\text { Pressure }\end{array}$ & $\begin{array}{c}\text { Secondary } \\
\text { Barrier }\end{array}$ \\
\hline \multirow{2}{*}{$\begin{array}{c}\text { Independent } \\
\text { tank }\end{array}$} & Type A & $<0.7$ & Full \\
\cline { 2 - 4 } & Type B & $<0.7$ & Partial \\
\cline { 2 - 4 } & Type C & $>2.0$ & No \\
\hline Integrated tank & $\begin{array}{c}\text { Membrane } \\
\text { tank }\end{array}$ & $<0.7$ & Full \\
\hline
\end{tabular}

This stereotypical choice of tank types is being questioned as large ships should be equipped with sizable fuel LNG tanks. Traditionally, Type $\mathrm{C}$ tanks are cylinders. So, to store a huge amount of fuel LNG without BOG venting means to install several cylinders inside the ship. This design concept makes no sense considering their drawbacks of wasting space between the multiple cylinders as well as increasing piping, instruments, and operational complexity. An alternative approach is to install such non-pressure tanks as for large LNG carriers. However, several critical issues should be examined carefully before taking this approach, especially from the view point of generated BOGs and their handling over the conceivable operational modes of the ship. 


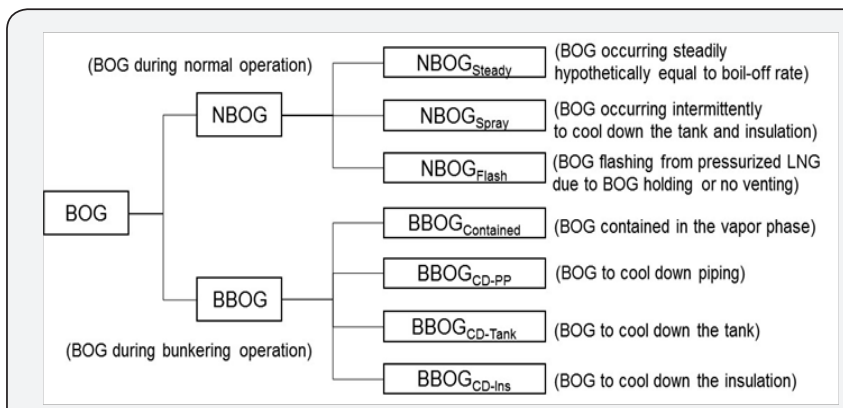

Figure 1: Classification of BOGs in terms of operational modes and origin.

Figure 1 classifies BOGs in terms of two main operational modes and their origin. During the normal operation mode where the stored LNG is used as fuel, three kinds of BOGs can be generated: $\mathrm{NBOG}_{\text {Steady }}, \mathrm{NBOG}_{\text {Spray' }}$, and $\mathrm{NBOG}_{\mathrm{Flash}}$. As the LNG bunkering consists of several steps [10], four additional BOGs should be considered for the bunkering operation. BBOGContained is the BOG inside the tank waiting for bunkering while the rest are related to cooling of the bunkering piping, the tank, and the insulation [11].

Due consideration should be paid to the following BOGrelated issues when a big non-pressure tank is considered for fuel LNG storage for ships.

a. The BOG generation rate during the normal operation can be greater than $\mathrm{NBOG}_{\text {stead }} \mathrm{y}$ due to the $\mathrm{NBOG}_{\text {spray }}$ that is caused by the intermittent cooldown of the upper parts of the tank and insulation.

b. Holding the BOG inside the tank for an extended period even below 0.2 barg can result in a huge amount of flashed BOG $\left(\mathrm{NBOG}_{\text {Flash }}\right)$.

c. Before the LNG bunkering, the BOG contained within the tank (BBOG Contained ) should be vented out of the tank and treated in an appropriate way. The current LNG bunkering infrastructure including bunkering ports and bunkering ships are not ready to receive the exported BOG from the ship. This means that the ship should be equipped with proper systems to reliquefy or burn the BOG.

d. During the LNG bunkering, BOG can be generated due to the cool down of the bunkering piping, the tank, and the insulation. Since this BOG also cannot be returned to the bunkering facility, the ship should digest it in an appropriate way.

e. The non-pressure tank cannot take LNG whose vapor pressure is greater than 0.2 barg while the current LNG bunkering infrastructure is usually supplying LNG at much higher pressure. So, the availability of the low-pressure LNG should be guaranteed.

Without addressing all these BOG issues, the use of nonpressure tanks for fuel LNG storage can hardly satisfy the performance goals of economics, safety, and environmental friendliness of ships, ports, and bunkering vessels.
Obviously, the best solution to fuel LNG storage in large scale would be a prismatic pressure vessel that could hold BOG and simultaneously fit into a limited installation space in a ship. The concept of the box-shape pressure vessel is not new in that ASME codes $[12,13]$ have already defined some rules for them. The challenge is how to scale up the prismatic tank without significantly increasing the tank weight. Recently, a new idea has been developed for the scalable prismatic vessel, called the lattice pressure vessel $[14,15]$. Unlike the conventional cylindrical pressure vessels, this tank employs an internal load bearing structure called the lattice structure. This technology may provide a solution to the fuel LNG storage for big ships satisfying both objectives of BOG holding and space efficiency.

\section{References}

1. IMO (2009) Regulations for the prevention of air pollution from ships, revised MARPOL Annex VI. International Maritime Organization, London, UK.

2. Devanney J (2011) The impact of the energy efficiency design index on very large crude carrier design and $\mathrm{CO}_{2}$ emissions. Ships Offshore Struct 6(4): 355-368.

3. DNV-GL (2017) Maritime in FOCUS-LNG as SHIP FUEL: A focus on the current and future use of LNG as fuel in shipping, Norway.

4. IMO (2008) International code for the construction and equipment of ships carrying liquefied gases in bulk (IGC Code). International Maritime Organization, London.

5. IMO (2009) Interim guidelines on safety for natural gas-fuelled engine installations in ships (IGF Code). International Maritime Organization, London.

6. Chang D, Rhee T, Nam K, Chang K, Lee D, et al. (2008) A study on availability and safety of new propulsion systems for LNG carriers. Reliab Eng Syst Saf 93(12): 1877-1885.

7. ABS (2015) Guide for building and classing liquefied gas carriers with independent tanks-hull structural design and analysis. American Bureau of Shipping, Houston, Texas, USA.

8. Seo YK, You HL, Lee SH, Huh C, Chang D (2015) Evaluation of $\mathrm{CO}_{2}$ liquefaction processes for ship-based carbon capture and storage (CCS) in terms of life cycle cost (LCC) considering availability, International Journal of Greenhouse Gas Control 35: 1-12.

9. Seo S, Chu B, Noh Y, Jang W, Lee S, et al. (2016) An economic evaluation of operating expenditures for LNG fuel gas supply systems onboard ocean-going ships considering availability, Ships Offshore Structures 11(2): 213-223.

10. Rysst J (2011) Bunkering and operation of gas fuelled ships. Proceedings of the Gasskonferansen; Bergen, Norway, p. 4.

11. Han SH, Chang D (2012) Optimum residence time analysis for a walking beam type reheating furnace. International Journal of Heat and Mass Transfer 55 (15-16): 4079-4087.

12. ASME (2010) ASME boiler and pressure vessel code, section VIII, division 1. The American Society of Mechanical Engineers, New York, USA.

13. ASME (2010) ASME boiler and pressure vessel code, section VIII, division 2. The American Society of Mechanical Engineers, New York, USA.

14. Ahn J (2012) Concept design of pressurized LNG fuel storage tank for large carriers [master's thesis]. Advanced Institute of Science and Technology.

15. http://www.lattice-technology.com/ab-484 
This work is licensed under Creative Commons Attribution 4.0 Licens DOI:_10.19080/OFOAJ.2017.01.555568
Your next submission with Juniper Publishers will reach you the below assets

- Quality Editorial service

- Swift Peer Review

- Reprints availability

- E-prints Service

- Manuscript Podcast for convenient understanding

- Global attainment for your research

- Manuscript accessibility in different formats ( Pdf, E-pub, Full Text, Audio)

- Unceasing customer service

Track the below URL for one-step submission https://juniperpublishers.com/online-submission.php 